\title{
Alteration of Pseudomonas aeruginosa respiration by 4-(1-adamantyl)-phenol derivative
}

\author{
Daria M. Dudikova ${ }^{1^{*}}$, \\ Nina O. Vrynchanu ${ }^{1}$, \\ Valentyna I. Nosar ${ }^{2}$ \\ ${ }^{1}$ Laboratory of Antimicrobial \\ Pharmacology, State Institution Institute \\ of Pharmacology and Toxicology, \\ National Academy of Medical \\ Sciences of Ukraine, \\ 14 Antona Tsedika St., \\ Kyiv 03057, Ukraine \\ ${ }^{2}$ Department of Hypoxia, \\ Bogomoletz Institute of Physiology, \\ National Academy of Sciences of Ukraine, \\ 4 Bogomoletz St., Kyiv 01024, Ukraine
}

\begin{abstract}
Derivatives of 4-(1-adamantyl)-phenol are a promising class of antimicrobials affecting the structural integrity and functions of the bacterial cell membrane. The functioning of Pseudomonas aeruginosa respiratory chain and related system of oxidative phosphorylation was investigated before and after treatment with a derivative of 4-(1-adamantyl)-phenol (compound KVM-97). Oxygen consumption was measured polarographically with a Clark-type oxygen electrode. KVM- 97 was tested at $0.5 \times$ and $1.0 \times$ MIC (minimum inhibitory concentration). Specific substrates of the respiratory chain (either $3.0 \mathrm{mM}$ glutamate with $2.0 \mathrm{mM}$ malonate or $3.0 \mathrm{mM}$ succinate with $5.0 \mu \mathrm{M}$ rotenone) were used. All reactions were stimulated by addition of ADP $(0.2 \mathrm{mmol})$. It was found that at tested concentrations, KVM-97 inhibited the endogenous respiration and substrate oxidation in P. aeruginosa cells. The inhibiting effect was dose-dependent and more pronounced with succinate oxidation rather than glutamate oxidation. The respiratory control index value (RCI) in compound-treated cells was in average 1.5 times lower compared to the intact cells. The decrease in the RCI was related to changing the oxygen uptake rates in state 3 and state 4 , which indicate the uncoupling of respiration and oxidative phosphorylation. The data obtained showed that 4-(1-adamantyl)-phenol derivative inhibits oxygen consumption and has uncoupling effects in P. aeruginosa cells.
\end{abstract}

Keywords: Pseudomonas aeruginosa, adamantane derivative, antibacterial agents, respiration

\section{INTRODUCTION}

Pseudomonas aeruginosa is an opportunistic human pathogen causing a wide range of life-threatening acute and chronic infections, including cystic

\footnotetext{
* Corresponding author. Email: dudikova@ift.org.ua
}

fibrosis, pneumonia, bacteraemia, infections of the urinary tract, and wounds (Page, 2009; Tielen, 2013; Turner, 2014; Yayan, 2015). According to the WHO list of "priority pathogens", $P$. aeruginosa is one of twelve microorganisms for which new antibacterial agents are most desperately needed (Tacconelli, 2017). The main challenges in 
the treatment of Pseudomonas infections are low pathogen susceptibility to the majority of antimicrobial agents, high virulence, and the ability of biofilm formation. Interestingly, the synthesis of both virulence factors and biofilm components (e.g., alginate) depends on oxygen availability and energy metabolism (Williams, 2006). Therefore, the energy-generating pathways could be considered one of the potential drug targets for the development of the novel antibacterial agents that (1) could kill microbial cells and (2) decrease the severity of disease course.

It is well-known that most antibiotics are able to alter bacterial metabolism and respiration. It was shown that bacteriostatic antibiotics decelerate cellular respiration whereas bactericidal antibiotics demonstrate an opposite action (Lobritz, 2015). Thus, chloramphenicol decreases the oxygen uptake during glucose oxidation (Duncan, 1962); quinolones (ciprofloxacin and pefloxacin) and $\beta$-lactams (meropenem) suppress the endogenous respiration in P. aeruginosa cells (Majtan, 1998).

Our previous results showed that derivatives of 4-(1-adamantyl)-phenol possess a strong potential to consider them antimicrobial and antibiofilm agents. Although the mode of action of the adamantane derivatives is largely unknown, our findings suggest that these compounds affect the structural integrity and functions of the bacterial cell membrane. We hypothesized that treatment of bacteria with adamantane derivatives alters oxidative metabolism and such changes may be reflected as violation of the energy generating pathways. The studies described in this paper were conducted with a view to provide the further information on the mode of antimicrobial action of 4-(1-adamantyl)-phenol derivatives.

\section{MATERIALS AND METHODS}

\section{Bacteria and media}

The strain Pseudomonas aeruginosa 2094 was isolated from a patient suffering from nosocomial infection. Mueller-Hinton broth ( $\mathrm{pH}$ 7.2) (HiMedia) and Tryptic soy broth (pH 7.2) (HiMedia) were used for minimal inhibitory con- centration (MIC) determination and for oxygen consumption experiments, respectively.

\section{Materials}

A derivative of 4-(1-adamantyl)-phenol (compound KVM-97) was synthesized in the Institute of Organic Chemistry of the National Academy of Sciences of Ukraine (Kyiv, Ukraine) by Yu. V. Korotkiy. KVM-97 was diluted in 10\% dimethyl sulfoxide (DMSO); stock solution concentration was $1 \mathrm{~g} / \mathrm{L}$. All other chemicals were obtained from commercial sources.

\section{Susceptibility to adamantane derivative}

MIC was determined by the serial broth macrodilution method according to the EUCAST recommendations. The inoculum density was $10^{6} \mathrm{CFU} / \mathrm{ml}$ culture medium, $24 \mathrm{~h}$ culture was used for its preparation. The lowest concentration of KVM-97 that inhibited bacterial growth was considered the MIC.

\section{Respiration measurement}

Oxygen consumption was measured polarographically with a Clark-type oxygen electrode (Hansatech, UK). Bacteria cells were grown aerobically at $37^{\circ} \mathrm{C}$ for $20 \mathrm{~h}$ in broth. Resting cell suspension was centrifuged at $5000 \mathrm{~g}$ for $10 \mathrm{~min}$, washed twice with a buffer solution of $18 \mathrm{mM} \mathrm{KH}_{2} \mathrm{PO}_{4}, 125 \mathrm{mM} \mathrm{KCl}, 5 \mathrm{mM}$ EDTA, $1 \mathrm{mM} \mathrm{MgCl}_{2}$ ( $\left.\mathrm{pH} 7.4\right)$, and resuspended in the same solution. The cell suspension $(0.8 \mathrm{ml})$ was stirred in a thermostated chamber at $35^{\circ} \mathrm{C}$ during the measurement. The oxygen concentration in suspension at $35^{\circ} \mathrm{C}$ was considered as $205 \mu \mathrm{M}$. In the experiments with substrates, either glutamate $(3.0 \mathrm{mM})$ and malonate $(2.0 \mathrm{mM})$, or succinate $(3.0 \mathrm{mM})$ and rotenone $(5.0 \mu \mathrm{M})$ were added with a microsyringe to the centre of the chamber. All reactions were stimulated by addition of ADP $(0.2 \mathrm{mM})$. KVM-97 was added to achieve different concentrations: $0.5 \times$ MIC and 1.0× MIC. Oxygen consumption was monitored for approximately $7 \mathrm{~min}$ and the linear part of the oxygen uptake curve was used to determine the respiration rates. The oxygen consumption rate was expressed as nanomoles of oxygen consumed per 
minute, corresponding to the total protein of cells. Protein concentration was determined by the method of Lowry et al. with bovine serum albumin as the standard (Lowry, 1951).

The ADP-stimulated respiration rate (state 3 ) was registered after addition of ADP to test suspension. The slower respiration rate, after complete ADP phosphorylation to ATP, was considered as state 4 . The respiratory control index (RCI), defined as the ratio of the oxygen uptake rates in state 3 compared with state 4 , was used for the evaluation of the uncoupling of respiration and oxidative phosphorylation (Manole, 2006).

\section{Statistical analysis}

The data were expressed as mean \pm standard deviation (SD). The statistical significance of differences between the groups was determined by the non-parametric Kruskal-Wallis test. The number of samples per group $(n)$ is noted in the figure legend. The statistical significance threshold of $p<0.05$ was applied.

\section{RESULTS}

\section{Effect of KVM-97 on the endogenous respira- tion}

The MIC value of KVM-97 for P. aeruginosa strain of was determined as $50 \mathrm{mg} / \mathrm{L}$. The alterations of the endogenous respiration of compound-treated $P$. aeruginosa cells are demonstrated in Table. The treatment of $P$. aeruginosa with KVM-97 at 1.0 $\times$ MIC resulted in the most pronounced effect: the complete suppression of cellular respiration was observed. The respira- tory activity after addition of KVM-97 at subinhibitory concentration $0.5 \times$ MIC decreased from $20.0 \pm 1.1$ to $16.0 \pm 0.97 \mathrm{nmol} \mathrm{O} / \mathrm{min} /$ mg protein $(p<0.05)$. Thus, the addition of KVM-97 to endogenous respiring $P$. aeruginosa cells caused a deceleration in oxygen consumption. The respiration rate in compound-treated cells decreased with increasing of compound in the dose-dependent manner.

\section{Effect of KVM-97 on substrate respiration}

The effect of KVM-97 on respiration was examined in the presence of either glutamate or succinate as respiratory substrates. Malonate and rotenone were used as specific inhibitors of succinate-oxidizing and NADH-oxidizing systems, respectively.

The data presented in Table shows that the endogenous respiration rate was slightly stimulated by addition of both substrates. In the presence of glutamate, the oxygen consumption rate was $25.2 \pm 1.07 \mathrm{nmol} \mathrm{O} / \mathrm{min} / \mathrm{mg}$ protein, whereas succinate slightly increased the respiration rate to $27.6 \pm 1.1 \mathrm{nmol} \mathrm{O} / \mathrm{min} /$ mg protein (Fig. $1 \mathrm{~A}, \mathrm{~B}$ ).

The rate of glutamate oxidation was decreased to $18.0 \pm 1.02$ and $15.5 \pm 0.96 \mathrm{nmol}$ $\mathrm{O}_{2} / \mathrm{min} / \mathrm{mg}$ protein $(p<0.05)$ under action of KVM-97 at concentrations $0.5 \times$ and $1.0 \times$ MIC, respectively (Fig. $1 \mathrm{~A}$ ). The oxidation of succinate in the respiratory chain of $P$. aeruginosa was inhibited by KVM-97 in dose-dependent manner, the most pronounced decrease of oxygen consumption was observed in the presence of KVM-97 at concentration 1.0× MIC (Fig. $1 \mathrm{~B}$ ).

Table. Oxygen consumption of the $P$. aeruginosa in the presence and absence of different substrates $(n=5)$

\begin{tabular}{|c|c|c|c|}
\hline \multirow{3}{*}{ Experimental conditions } & \multicolumn{3}{|c|}{ Activity, $\mathrm{nmol} \mathrm{O}_{2} \mathrm{~min}^{-1} \mathrm{mg}^{-1}$} \\
\hline & \multirow{2}{*}{ Control } & \multicolumn{2}{|c|}{ KVM-97 } \\
\hline & & $0.5 \times \mathrm{MIC}$ & $1.0 \times \mathrm{MIC}$ \\
\hline Without substrates (endogenous respiration) & $20.0 \pm 1.1$ & $16.0 \pm 0.97 \#$ & ND \\
\hline Glutamate & $25.2 \pm 1.07$ & $18.0 \pm 1.02 \#$ & $15.5 \pm 0.96 \#$ \\
\hline Succinate & $27.6 \pm 1.1$ & $25.0 \pm 0.93$ & $\mathrm{ND}$ \\
\hline
\end{tabular}

Note: $\# p<0.05$ comparatively to control intact cells in each group, ND - respiration activity not determined, complete depression of respiration. 

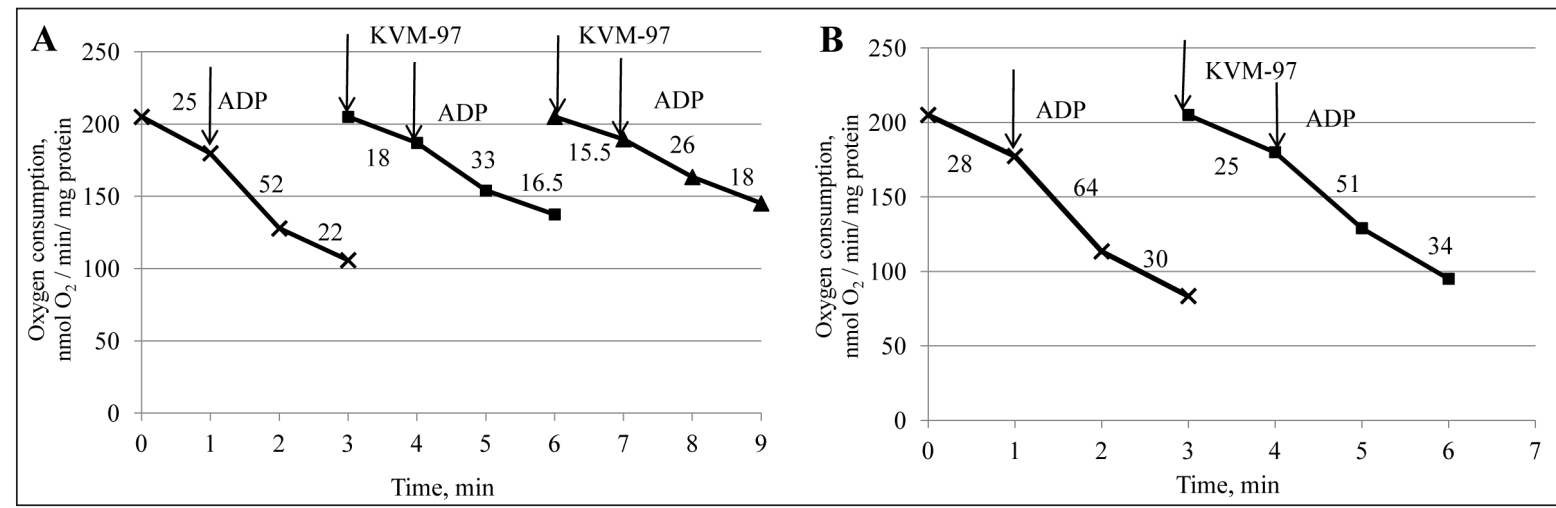

Fig. 1. Effect of adamantane derivative KVM-97 on P. aeruginosa respiration and oxidative phosphorylation in presence of substrates $(n=5)$

Oxygen consumption was measured using a Clark type oxygen electrode. The reaction mixture contained $0.8 \mathrm{ml}$ of cells suspension (1.0 mg of protein) in a total volume of $1.0 \mathrm{ml}$. In (A), $3.0 \mathrm{mM}$ of glutamate and $2.0 \mathrm{mM}$ of malonate were first added to the mixture, and then KVM-97 solution $(0.5 \times$ MIC or $1.0 \times$ MIC) was added. In (B), $3.0 \mathrm{mM}$ of succinate and $5.0 \mu \mathrm{M}$ of rotenone were first added to the mixture, and then KVM-97 solution was added. All reactions were stimulated by addition of $0.2 \mathrm{mM}$ of ADP. $\times--\times$ - intact control cells; ---- - cells in presence of KVM-97 0.5 $\times$ MIC; $\boldsymbol{\Delta - -} \boldsymbol{\Delta}$ - cells in presence of KVM-97 1.0 $\times$ MIC. The arrows indicate the time of addition of either KVM-97 or ADP.

It was found that, at the highest concentration, KVM-97 did not cause complete depression of substrate respiration in the presence of glutamate, unlike both succinate oxidation and non-substrate endogenous respiration.

\section{Effect of KVM-97 on the oxidative phospho- rylation}

Oxidative phosphorylation was assessed by state 3 , state 4 respiration rates, and the RCI in compound-treated and intact cells.
It was observed (Fig. $1 \mathrm{~A}$ ) that in the presence of glutamate, addition of the test-compound in both concentrations led to reduction of the respiration rates of state 3 and state 4 by $36.5-49.8 \%$ and $16.8-25.0 \%$, respectively. Uncoupling of the respiratory chain was manifested in RCI decrease from $2.37 \pm 0.19$ to $1.45 \pm 0.15(p<0.05)$ (Fig. $2 \mathrm{~A})$.

In contrast, in the presence of succinate and KVM-97 (0.5× MIC), state 3 respiration rate decreased by $25 \%$ whereas state 4 respiration
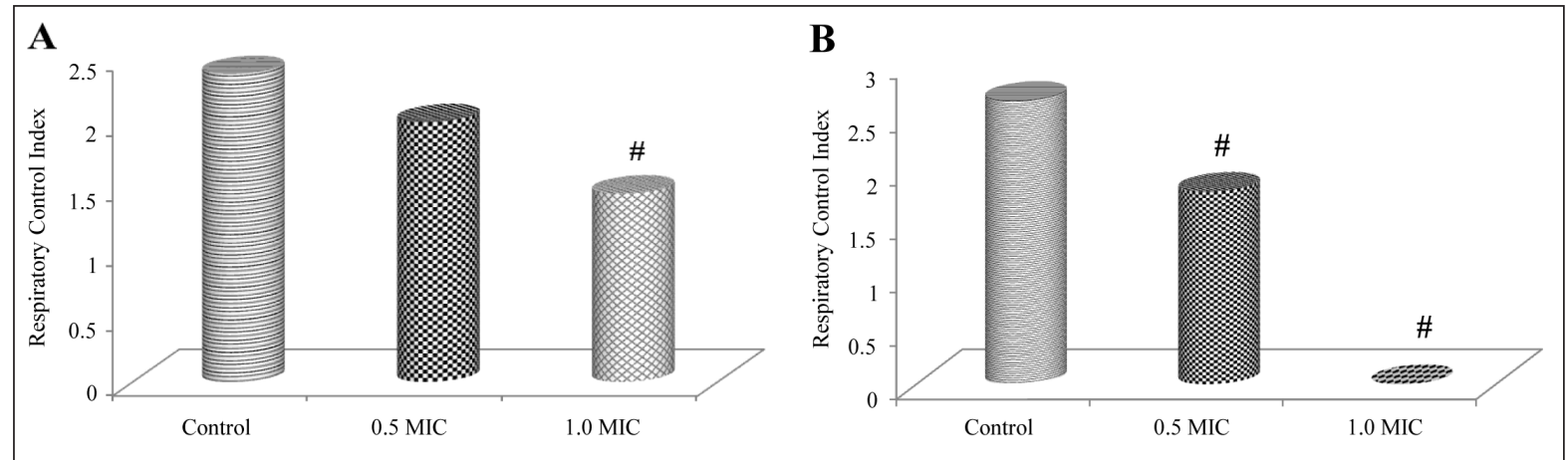

Fig. 2. Effect of KVM-97 on respiratory control index of Pseudomonas aeruginosa $(n=5)$

Note: $\# p<0.05$ comparatively to control intact cells 
rate increased slightly (up to $11 \%$ ) (Fig. $1 \mathrm{~B}$ ). The RCI value decreased from $2.65 \pm 0.18$ to $1.80 \pm 0.30(p<0.05)$ (Fig. 2 B). The higher KVM-97 concentration (1.0× MIC) completely inhibited $P$. aeruginosa respiration.

Therefore, KVM-97 depressed ADP-stimulated substrate respiration of $P$. aeruginosa in a dose-dependent manner. The inhibiting effect was more pronounced with succinate oxidation rather than glutamate oxidation. The RCI value in compound-treated cells was in average 1.5 times lower compared to the intact cells, indicating the uncoupling of the respiration and oxidative phosphorylation.

\section{DISCUSSION}

The decrease of the efficacy of antibiotic therapy and the spread of resistant pathogens constantly demand discovery and development of new antibiotics with novel mechanism of action. One of the potential targets for pharmacotherapy is energy generation process in microbial cells. $P$. aeruginosa aerobic respiratory chain is assembled in the cytoplasmic membrane. It has at least 17 primary dehydrogenases, ubiquinone and b- and c-type cytochromes, as well as five terminal oxidases (Matsushita, 1980; Williams, 2006). Pseudomonas cells can synthesize virulence factors (e.g., cyanide) in the process of energy generation in the respiratory chain. Apparently, the same metabolic pathways may be involved in the biofilm development whereas alginate biosynthesis, one of the main components of $P$. aeruginosa biofilm matrix, is an energy-dependent process. Moreover, numerous data suggest the major role of oxygen availability for the biofilm growth and metabolic activity.

Our previous results showed that derivatives of 4-(1-adamantyl)-phenol possess a strong potential to consider them as antimicrobial and antibiofilm agents. Adamantane derivative KVM-97 is lipophilic compound and rapid integration into the cellular membranes is likely to occur.

In this paper we presented the evidence that KVM-97 significantly depressed the endogenous respiration and succinate oxidation in $P$. aeruginosa cells. Compound treatment result- ed in alteration of state 3 and state 4 respiration, and RCI as well, indicating the uncoupling of the respiration and oxidative phosphorylation.

Interestingly, the addition of KVM-97 at 1.0× MIC to $P$. aeruginosa cells did not cause complete inhibition of glutamate-dependent respiration, unlike the non-substrate endogenous respiration and succinate oxidation. We hypothesized that KVM-97 affect glutamate-dependent metabolic processes as glutamate excess prevent compound-induced inhibition of respiration.

It is well known that glutamate plays the central role in a wide range of metabolic processes in bacterial cells. This nonessential amino acid is involved in protein synthesis and other fundamental processes such as glycolysis, gluconeogenesis and the citric acid cycle. It is also a key metabolite, because it serves as a link between nitrogen and carbon metabolism (Berezov, 2004). Glutamate is important for the ammonia assimilation as well. Proteins or amino acids are implicated as the source of ammonia, the end product of endogenous respiration of $P$. aeruginosa (Warren, 1960).

Therefore, the antimicrobial and antibiofilm mechanism of action of the adamantane derivatives may be associated with a violation of the bacterial respiratory chain. Used in clinical practice, antibiotics may also alter bacterial cellular metabolism and respiration. Thus, chloramphenicol decreased the oxygen uptake in $P$. aeruginosa during glucose oxidation and appeared to inhibit the oxidation of $\alpha$-ketoglutaric acid to glutamate (Duncan, 1962).

\section{CONCLUSIONS}

In the present study we demonstrated the alteration of oxygen consumption in P. aeruginosa cells caused by the 4-(1-adamantyl)-phenol derivative. The results suggest that KVM-97 inhibits the endogenous respiration and substrate oxidation and has an uncoupling effect in $P$. aeruginosa cells in dose-dependent manner. The mode of action of KVM-97 is related to the effect on glutamate-dependent metabolic processes, because glutamate excess prevented compoundinduced inhibition of respiration in P. aeruginosa 
cells. Further studies are obviously required, which might provide valuable information about the role of adamantane derivatives in the disturbance of energy-dependent pathways.

Received 5 December 2017

Accepted 26 June 2018

\section{References}

1. Berezov TT, Korovkin BF. Biological chemistry. Moscow, M: Medicine. 2004; 704. Russian.

2. Duncan MG, Campbell JJ. Oxidative assimilation of glucose by Pseudomonas aeruginosa. J Bacteriol. 1962; 84(4): 784-92.

3. Lobritz MA, Belenky P, Porter CB, et al. Antibiotic efficacy is linked to bacterial cellular respiration. Proceedings of the National Academy of Sciences. 2015; 112(27): 8173-80.

4. Lowry OH, Rosebrough NJ, Farr AL, Randall RJ. Protein measurement with the Folin phenol reagent. J Biol Chem. 1951; 193: 265-75.

5. Majtan V, Majtanova L. Postantibiotic effect of some antibiotics on the metabolism of Pseudomonas aeruginosa. J Basic Microbiol. 1998; 38(2): 221-7.

6. Manole A, Apostu MO, Neascu I, Melnig V. Membrane covered polarographic oxygen manufacturing. Practical aspects. Analele Stiint Ale Univ. 2006; II: 35-42.

7. Matsushita K, Yamada M, Shinagawa E, Adachi O, Ameyama M. Membrane-Bound respiratory chain of Pseudomonas aeruginosa grown aerobically. J Bacteriol. 1980; 141(1): 389-92.

8. Page MG, Heim J. Prospects for the next antiPseudomonas drug. Curr Opin Pharmacol. 2009; 9(5): 558-65.

9. Tacconelli E, Magrini N, Carmeli Y, et al. Global priority list of antibiotic-resistant bacteria to guide research, discovery, and development of new antibiotics [Internet]. 2017. World Health Organization. Available from: http://www. who.int/medicines/publications/global-priority-list-antibiotic-resistant-bacteria/en/ [Cited 2017 May 16].

10. Tielen P, Rosin N, Meyer A-K, Dohnt K, Haddad I, Jänsch L, et al. Regulatory and metabolic networks for the adaptation of Pseudomonas aeruginosa biofilms to urinary tract-like conditions. PLoS ONE. 2013; 8(8): e71845.

11. Turner KH, Everett J, Trivedi U, Rumbaugh KP, Whiteley M. Requirements for Pseudomonas aeruginosa acute burn and chronic surgical wound infection. PLoS Genetics. 2014; 10(7): e1004518.

12. Warren RAJ, Ells AF, Campbell JJR. Endogenous respiration of Pseudomonas aeruginosa. J Bacteriol. 1960; 79(6): 875-9.

13. Williams HD, Zlosnik JE, Ryall B. Oxygen, cyanide and energy generation in the cystic fibrosis pathogen Pseudomonas aeruginosa. Adv Microb Physiol. 2006; 52: 1-71.

14. Yayan J, Ghebremedhin B, Rasche K. Antibiotic resistance of Pseudomonas aeruginosa in pneumonia at a single university hospital center in Germany over a 10-year period. PLoS ONE. 2015; 10(10): e0139836.

\section{Daria M. Dudikova, Nina O. Vrynchanu, Valentyna I. Nosar}

\section{4-(1-ADAMANTIL)-FENOLIO JUNGINIO NULEMTI PSEUDOMONAS AERUGINOSA KVĖPAVIMO SISTEMOS PAKITIMAI}

\section{Santrauka}

4-(1-adamantil)-fenolio junginiai yra perspektyvi antimikrobinių medžiagų klasè, turinti įtakos bakterijų ląstelių membranos struktūriniam vientisumui ir funkcijoms. Pseudomonas aeruginosa kvèpavimo grandinès ir su oksidaciniu fosforilinimu susijusių sistemų funkcionavimas buvo tirtas prieš ir po 4-(1-adamantil)-fenolio (KVM-97 junginys) panaudojimo. Deguonies sunaudojimas buvo matuojamas poligrafiškai su Klarko tipo deguonies elektrodais. KVM-97 matuotas $0,5 \times$ ir $1.0 \times$ MIC (minimalioje 
slopinimo koncentracijoje). Naudoti specifiniai kvèpavimo grandinès substratai $-3,00 \mathrm{mM}$ glutamatas su 2,00 mM malonatu arba $3,00 \mathrm{mM}$ sukcinatas su 5,0 $\mu$ Mrotenonu.Visosreakcijosbuvosužadintos ADP (0,2 mmol). Tyrimo metu nustatyta, kad KVM-97 matuotomis koncentracijomis slopino endogenini kvèpavimą ir substrato oksidaciją P. aeruginosa ląstelèse. Slopinantis poveikis priklausè nuo dozès dydžio ir buvo ryškesnis sukcinato nei glutamato oksidacijoje. Kvejpavimo kontrolès indeksas (RCI) junginiu paveiktose ląstelèse buvo 1,5 karto mažesnis nei nepaveiktose. RCI sumažejimas yra susijęs su deguonies ịsisavinimo pokyčiu 3 ir 4 būsenoje ir liudija kvèpavimo ir oksidacinio fosforilinimo blokavimą. Gauti duomenys rodo, kad 4-(1-adamantil)-fenolio junginiai slopina $P$. aeruginosa ląstelių deguonies sunaudojimą ir pasižymi blokuojančiu poveikiu.

Raktažodžiai: Pseudomonas aeruginosa, adamantano junginys, antibakteriniai preparatai, kvèpavimas 